\title{
Compliance, illiteracy and low-protein diet: multiple challenges in CKD and a case of self-empowerment
}

\author{
Stefania Maxia ${ }^{1}$, Valentina Loi ${ }^{1}$, Irene Capizzi ${ }^{2}$, Giorgina Barbara Piccoli ${ }^{2,3}$, Gianfranca Cabiddu ${ }^{1 *}$ and Antonello Pani
}

\begin{abstract}
Background: Low-protein diets (LPD) are an important means of delaying the need for dialysis and attaining a stable metabolic balance in chronic kidney disease (CKD). Many authors consider a low educational level and illiteracy to be adverse features for a good dietary compliance.

Case presentation: We report the case of a 77-year old woman, illiterate, affected by advanced CKD (stage 4 according to KDIGO guidelines). She was initially ashamed of her problem and did not declare it, leading to an overzealous reduction in protein intake. However, with her daughter's help, who translated the dietary prescription into images, she overcame the barrier represented by illiteracy and was able to correctly follow the prescriptions, attaining good kidney function stability and preserving an adequate nutritional status.
\end{abstract}

Conclusions: The case underlines the importance of a personalized approach to dietary prescriptions and suggests that it is possible to achieve a good compliance to the dietary treatment of CKD also in patients with relevant cultural barriers.

Keywords: Case report, Illiteracy, Low protein diet, Chronic kidney disease, Compliance

\section{Background}

Low protein diets are considered effective tools in reducing proteinuria, correcting and preventing signs, symptoms, and complications of chronic kidney disease (CKD), delaying the start of dialysis, preventing malnutrition and providing cardiovascular protection [1].

The use of low-protein diets is still open for debate. Besides the risk of malnutrition, the main reason why many authors feel diets are not worth prescribing is that it is often met with poor compliance, especially when the diet is combined with the complex therapies that are usually needed in our patients with advanced CKD [2-6].

Adherence to the prescriptions is also linked to the educational level; however, recent studies have underlined that the educational level may not be an absolute barrier in motivating patients and attaining compliance [7, 8]. While patients usually prefer direct counselling with the caregivers, visual aids may be useful in improving

\footnotetext{
* Correspondence: gianfranca.cabiddu@tin.it

'SC Nephrology and Dialysis, Brotzu Hospital, Piazzale Alessandro Ricchi 1, 09134 Cagliari, Italy

Full list of author information is available at the end of the article
}

compliance [9]. Their potential limitation may be the lack of correspondence to a shared language, particularly in patients with a low educational level [9-11].

Illiteracy, justly considered a "silent epidemic", is not negligible in several areas, including developed countries, especially in elderly patients. The importance of illiteracy was underlined in a recent case report published in New England Journal of Medicine, showing how low compliance to anti-diabetic drugs was resolved by the "diagnosis" of illiteracy [12].

Our case report describes an illiterate patient with severe CKD, who created with her daughter a clear and simple visual aid allowing good compliance; her story calls once more for attention to this neglected social and clinical problem, and conversely suggests that illiterate patients may provide important lessons on compliance and empowerment. While warning against discrimination of patients with a low educational level, this case underlines the importance of taking time in the clinical practice to consider cultural barriers which could potentially impair the success of the care in CKD patients. 


\section{Case presentation}

A 77 years old woman was referred in 2014 to our outpatient unit dedicated to advanced CKD in the Brotzu Hospital in Cagliari, Sardini, from a different nephrology unit where she had been followed since 2005. In 2006, a kidney biopsy led to the diagnosis of focal and segmental glomerulonephritis with advanced tubular interstitial damage.

Her clinical history was characterised by long-lasting hypertension (for at least 30 years). In 2011, she underwent total thyroidectomy, due to a multi-nodular colloid-cystic goitre. In 2013, she underwent a radical left mastectomy for a ductal infiltrating carcinoma (G2 pT2 pN3) and was treated afterwards with radiotherapy and aromatase inhibitor. Furthermore, in the past few years, she had lost a considerable number of teeth and suffered from chewing difficulties.

The patient had been referred to our unit because of a rapid worsening of her kidney function, with an estimated Glomerular Filtration Rate (eGFR), calculated with the Chronic Kidney Disease - Epidemiology Collaboration (CKD-EPI) formula that decreased from 25 to $16 \mathrm{ml} / \mathrm{min}$ in five months. An in-depth history and a basic workout had ruled out the most common causes of rapid worsening of the renal function, including dehydration caused by infectious illness or by climatic conditions, ingestion of NSAIDs or any other drug out of those prescribed, cardiac, and vascular disease. At referral, her therapy included levothyroxine $100 \mathrm{mcg}$, furosemide $50 \mathrm{mg}$, losartan $50 \mathrm{mg}$, lercarnidipine $10 \mathrm{mg}$, ramipril $10 \mathrm{mg}$, allopurinol $150 \mathrm{mg}$, ezetimibe $10 \mathrm{mg} /$ simvastatin $20 \mathrm{mg}$, calcium carbonate $1.25 \mathrm{~g}$ twice a day and cholecalciferol 25,000 UI every other week.

The patient lived with her husband and had had four children; a son and a daughter lived close by. One son had been on hemodialysis and had died at the age of 48 years from sepsis.

The patient, living in the countryside, was illiterate, a rare but not exceptional situation in her age group in our region [13].

At the first physical evaluation, the patient was overweight $\left(67 \mathrm{~kg}, 154 \mathrm{~cm}\right.$, BMI $\left.28.3 \mathrm{~kg} / \mathrm{m}^{2}\right)$ and the blood pressure control was suboptimal (PA 150/ $90 \mathrm{mmHg}$ without difference in orthostatism).

The main biochemical data and the treatments are reported in Tables 1 and 2. Of note, she was on an association of angiotensin converting enzyme inhibitors (ACEi) and angiotensin receptor blockers (ARBs), which is employed in our setting in patients with nephrotic syndrome, and which was continued, in the absence of hyperkalemia at circa-monthly blood tests, also on account of the anamnestic data of a sharp increase in proteinuria if one of the two drugs was discontinued.
Table 1 Clinical and laboratory parameters

\begin{tabular}{|c|c|c|c|c|}
\hline & & Pre diet ${ }^{a}$ & $\begin{array}{l}\text { Pre visual aid } \\
\text { (after diet start) }\end{array}$ & $\begin{array}{l}\text { Post visual aid } \\
\text { (1 year later) }\end{array}$ \\
\hline Body weight & $(\mathrm{Kg})$ & 68 & 60,500 & 60 \\
\hline Creatinine & $(\mathrm{mg} / \mathrm{dL})$ & 2.35 & 3.79 & 2.61 \\
\hline eGFR CKD-EPI & $(\mathrm{mL} / \mathrm{min})$ & 19 & 11 & 17 \\
\hline Bun & $(\mathrm{mg} / \mathrm{dL})$ & 67 & 84 & 76 \\
\hline Sodium & $(\mathrm{mEq} / \mathrm{L})$ & 139 & 137 & 141 \\
\hline Potassium & (mEq/L) & 4.4 & 4.9 & 4.6 \\
\hline Calcium & $(\mathrm{mg} / \mathrm{dL})$ & 9.7 & 8.9 & 8.6 \\
\hline Phosphorus & $(\mathrm{mg} / \mathrm{dL})$ & 4.4 & 4.8 & 4.3 \\
\hline Urine volume & $(\mathrm{mL})$ & 2700 & 1650 & 2300 \\
\hline Proteinuria & (g/day) & 2.73 & 0.65 & 1 \\
\hline Hemoglobin & $(\mathrm{g} / \mathrm{dL})$ & 11.4 & 9.9 & 9.4 \\
\hline Urinary urea & (g/day) & 6.12 & 4.46 & 7.31 \\
\hline Mitch formula & (g/kg/day) & 0.5 & 0.42 & 0.57 \\
\hline $\mathrm{PH}$ & & 7.359 & 7.367 & 7.390 \\
\hline Bicarbonate & $(\mathrm{mmol} / \mathrm{L})$ & 34.2 & 30 & 29.3 \\
\hline Base excess & $(\mathrm{mmol} / \mathrm{L})$ & 7.44 & 3.87 & 3.97 \\
\hline Total protein & $(\mathrm{g} / \mathrm{dL})$ & 7.7 & - & 7.2 \\
\hline Albumin & $(\mathrm{g} / \mathrm{dL})$ & 4.4 & 4.3 & 3.9 \\
\hline Glucose & $(\mathrm{mg} / \mathrm{dl})$ & 90 & 89 & 77 \\
\hline Tot cholesterol & $(\mathrm{mg} / \mathrm{dL})$ & 195 & 124 & 107 \\
\hline HDL Cholesterol & $(\mathrm{mg} / \mathrm{dL})$ & 78 & 52 & 57 \\
\hline LDL Cholesterol & $(\mathrm{mg} / \mathrm{dL})$ & 91 & 55 & 33 \\
\hline Triglycerides & $(\mathrm{mg} / \mathrm{dL})$ & 129 & 87 & 84 \\
\hline Iron & $(\mathrm{ug} / \mathrm{dL})$ & 76 & 48 & 46 \\
\hline Transferrin & $(\mathrm{mg} / \mathrm{dL})$ & 129 & 147 & 189 \\
\hline Ferritin & (ng/mL) & 339 & 325 & 280 \\
\hline Folic acid & (ng/mL) & 6.3 & 6.6 & $>24$ \\
\hline PTH & $(\mathrm{pg} / \mathrm{mL})$ & 16 & 26 & 17 \\
\hline $\begin{array}{l}\text { 25- OH Vitamin } \\
\text { D }\end{array}$ & (ng/mL) & 32.5 & 38.6 & 32.5 \\
\hline
\end{tabular}

eGFR CKD-EPI eGFR calculated by means of CKD EPI formula, BUN Blood Urea Nitrogen, Mitch formula Protein intake/Kg, according to the Maroni Mitch formula [30], PTH parathyroid hormone

athe patient had received some generic counselling and was avoiding virtually all animal derived proteins

The dietary history revealed a relatively high protein intake (estimated as above $1 \mathrm{~g} / \mathrm{Kg} /$ day on actual body weight by dietary recall) divided into three main meals and a midmorning snack, with a high consumption of pasta and bread. Since the importance of reduction in protein intake had been discussed in a previous clinical visit, at referral she had tried to self-manage her diet, resulting in an unbalanced low-protein diet, completely avoiding animal proteins and reducing the caloric intake. This overzealous attitude is a common and often underestimated problem in particular in elderly patients 
Table 2 Therapy

\begin{tabular}{llll}
\hline & Pre diet* & Pre visual aid (after diet start) & Post visual aid (1 year later) \\
\hline Levothyroxine & $100 \mathrm{mcg}$ & $100 \mathrm{mcg}$ for 6 days/week, $50 \mathrm{mcg}$ for 1 day/week & $100 \mathrm{mcg}$ for 6 days/week \\
Furosemide & $25 \mathrm{mg} / \mathrm{twice}$ a day & $25 \mathrm{mg} /$ twice a day & $25 \mathrm{mg} /$ twice a day \\
Losartan & $50 \mathrm{mg}$ & $50 \mathrm{mg}$ & $50 \mathrm{mg}$ \\
Lercarnidipine & $10 \mathrm{mg}$ & discontinued & $/$ \\
Ramipril & $10 \mathrm{mg}$ & $10 \mathrm{mg}$ & $10 \mathrm{mg}$ \\
Allopurinol & $150 \mathrm{mg}$ & $150 \mathrm{mg}$ & $150 \mathrm{mg}$ \\
Ezetimibe/simvastatin & $10 \mathrm{mg} / 20 \mathrm{mg}$ & discontinued & $10 \mathrm{mg} / 20 \mathrm{mg}$ \\
Calcium carbonate & $1.25 \mathrm{~g} / \mathrm{twice}$ a day & $500 \mathrm{mg} / \mathrm{twice}$ a day & $/$ \\
Calcium acetate & $/$ & discontinued & $500 \mathrm{mg} /$ twice a day \\
Cholecalciferol & 25,000 Ul/every other week & $1 \mathrm{mg}$ & $/$ \\
Anastrozole & $1 \mathrm{mg}$ &
\end{tabular}

"scared" of dialysis. Almost paradoxically, in such cases, starting a "low protein diet" may lead to an increase in animal-derived proteins, to attain a stable balance, protective not only for the nutritional status but also for the renal function [14-18].

This was the case also in our patient. On account of the calculated previous protein intake, we attempted to re-equilibrate the diet by substituting the normal carbohydrates, on which the Italian diet is based, with protein-free food (notably available free of charge in Italy), with a target intake of $0.6 \mathrm{~g} / \mathrm{kg} /$ day (based on her actual body weight, which roughly corresponded to a $0.6 \mathrm{~g} / \mathrm{Kg} /$ day on ideal body weight), increasing at the same time the animal-derived proteins. The diet included a daily intake of $1.3 \mathrm{~g}$ of sodium, $2 \mathrm{~g}$ of potassium and $800 \mathrm{mg}$ of phosphorus.

At the first clinical visit after the diet prescription, kidney function was further reduced (Table 1), and the patient reported difficulties in following the prescribed diet (Fig. 1).

Notwithstanding her difficulties, the patient appeared motivated in following any advice that could postpone dialysis (mostly on account of having had a son on dialysis who had prematurely died), the family was involved in the counselling process and underwent extensive counselling during the following clinical visits.

At the following visit, overall compliance (including protein intake, caloric intake, and distribution of the food over the meals and food choice) was remarkably improved (Table 1). When asked how she had overcome her initial problems, the patient showed us the images reproduced in the Figs. 2, 3 and 4. Her daughter had built with her an extensive visual aid system, by translating the prescriptions into images taken from tabloids and advertisements, as shown. Indeed, it was only by this revelation that we discovered that our patient was illiterate, an issue that we had not taken into account, since she had hidden this information, being ashamed of her condition.
One and half years later, she was following the diet with good compliance, stable GFR and satisfactory nutritional status (Table 1). Indeed, this case made us reflect on more general terms on the difficulties in following complex diet plans, such as those proposed in our setting, and is leading us to shift towards a qualitative and simplified approach to low protein diets [19].

\section{Discussion}

This clinical case shows how a low protein diet could also be followed where the premise does not look promising. Illiteracy is indeed an important obstacle as the impossibility to rely on written aids makes the daily management more difficult.

When prescribing a diet, the evaluation of the education level is not a point to be underrated, as even the best possible diet would never be successful if not understood by the patient. Our patient presented with this huge barrier: she was illiterate, and she was consequently unable to follow a written diet; moreover, being ashamed of her lack of education, she did not declare it in the beginning. This is not an exceptional problem in our setting: in Sardinia, in the 1940s, the rate of illiteracy was quite high, especially in the countryside and among women. Within a farmer's family, children would generally start working from the earliest age possible and would not even attend primary school, which was the case for our patient [13].

When we realised this challenging problem, we decided not to give up because the patient, who had lost a son on haemodialysis, strongly refused the future option of renal replacement therapy.

A number of studies demonstrate an association between low educational level and low dietary compliance. Hadžiabdić analysed the factors that influence the adherence to low-calorie diets in overweight and obese patients and underlined how poor educational level is one of the negative predicting factors for a successful 


\begin{tabular}{|c|c|}
\hline \multicolumn{2}{|c|}{ BREAKFAST } \\
\hline $\begin{array}{l}\text { Semi-skimmed milk: } 150 \mathrm{ml} \mathrm{(1} \\
\text { glass) }\end{array}$ & $\begin{array}{l}\text { Or, as an alternative, one of the following: } \\
\text { - } \\
\text { plain whole-milk yogurt: } 125 \mathrm{~g}(1 \\
\text { cup) } \\
\text { fruity whole-milk yogurt: } 125 \mathrm{~g}(1 \\
\text { cup) } \\
\text { plain semi-skimmed yogurt: } 125 \\
\mathrm{~g}(1 \text { cup }) \\
\text { fruity semi-skimmed yogurt: } 125 \\
\mathrm{~g}(1 \text { cup })\end{array}$ \\
\hline $\begin{array}{l}\text { Protein-free melba toast } 30 \mathrm{~g}: \\
\text { or sliced protein-free bread } 70 \mathrm{~g}, \\
\text { protein-free sliced toasted bread } \\
\text { or protein-free breadsticks } 35 \mathrm{~g}, \mathrm{c} \\
\text { pastry } 40 \mathrm{~g} \text {, or protein-free vanill } \\
\text { protein-free pastry } 25 \mathrm{~g} \text {, or prote } \\
\text { protein-free cocoa and apricot sn } \\
\text { protein-free cocoa and vanilla des } \\
\text { protein-free apricot snack } 30 \mathrm{~g}, \mathrm{o} \\
\text { free unsweetened cocoa wafer } 30\end{array}$ & $\begin{array}{l}\text { oft protein-free french loaf } 40 \mathrm{~g} \text {, or } \\
\mathrm{g} \text {, or soft protein-free "rosetta" bread } 40 \mathrm{~g} \text {, } \\
\text { rotein-free biscuits } 40 \mathrm{~g} \text {, or protein-free } \\
\text { afer } 40 \mathrm{~g} \text {, or light unsweetened cocoa } \\
\text { ree pastry with chocolate drops } 25 \mathrm{~g} \text {, or } \\
30 \mathrm{~g} \text {, or protein-free cream pastry } 40 \mathrm{~g} \text {, or } \\
\text { t } 40 \mathrm{~g} \text {, or protein-free flour } 40 \mathrm{~g} \text {, or } \\
\text { otein-free vanilla dessert } 70 \mathrm{~g} \text {, or protein- }\end{array}$ \\
\hline
\end{tabular}

\begin{tabular}{|l|l|}
\hline \multicolumn{2}{|c|}{ MORNING SNACK } \\
\hline Type A fruit: $150 \mathrm{~g}$ & Or, as an alternative, one of the \\
Black cherries, oranges, & following: \\
strawberries, lemon, quince, & - Type B fruit: $150 \mathrm{~g}$ \\
cantaloupe, blueberries, pears, & Apricot, pineapple, cherries, \\
plums & watermelon, kiwi, raspberries, \\
& melon, blackberries, medlars, \\
& peaches, grapefruit \\
& Type C fruit: $80 \mathrm{~g}$ \\
& Clementines, persimmons, \\
& tangerines, apples, grapes \\
& Type D fruit: $80 \mathrm{~g}$ \\
& Bananas, figs, mandarins, \\
& pomegranates \\
\hline
\end{tabular}

\begin{tabular}{|c|c|}
\hline \multicolumn{2}{|r|}{ LUNCH } \\
\hline \multicolumn{2}{|c|}{$\begin{array}{l}\text { Durum wheat flour pasta } 70 \mathrm{~g} \\
\text { Or rice } 115 \mathrm{~g} \text {, or potato dumpling } 215 \mathrm{~g} \text {, egg pasta } 60 \mathrm{~g} \text {, or plain common bread } \\
95 \mathrm{~g} \text {, or cornmeal mush } 170 \mathrm{~g} \text {. Season the pasta with simple sauces (tomatoes } \\
\text { or vegetable). } \\
\text { Or, once a week, fresh legumes are allowed (fava beans, beans, peas) } 70 \mathrm{~g} \text {, or } \\
\text { well-washed and drained tinned legumes (chickpeas, beans, lentils, peas, fava } \\
\text { beans) } 90 \mathrm{~g} \text {. } \\
\text { It is permitted to add a spoon of cheese }(5 \mathrm{~g}) .\end{array}$} \\
\hline $\begin{array}{l}\text { Type A Vegetable: } 150 \mathrm{~g} \\
\text { Cucumber, onions, } \\
\text { aubergines, yellow pepper, } \\
\text { red radicchio. }\end{array}$ & $\begin{array}{l}\text { Or, as an alternative, one of the following: } \\
\text { Type B vegetable: } 130 \mathrm{~g} \\
\text { Red beetroot, chard, cardoon, carrot, } \\
\text { chicory, baby onion, fennel, endive, } \\
\text { sweet peppers, salad tomatoes, ripe } \\
\text { tomatoes, peeled tomatoes, turnip, } \\
\text { radish, yellow pumpkin, courgette } \\
\text { Type C vegetable: } 80 \mathrm{~g} \\
\text { Asparagus, broccoli, artichoke, } \\
\text { cauliflower, Brussels sprouts, red or } \\
\text { green cabbage, catalogna, sauerkraut, } \\
\text { watercress, green beans, courgette } \\
\text { flower, gallinacci mushrooms, ovuli } \\
\text { mushrooms, porcini mushrooms, field } \\
\text { mushrooms, lettuce, leek, green } \\
\text { radicchio, rocket, endive, celery } \\
\text { Type D vegetable: } 60 \mathrm{~g} \\
\text { chiodini mushrooms, spinach } \\
\end{array}$ \\
\hline \multicolumn{2}{|c|}{$\begin{array}{l}\text { Once a week potatoes are allowed }(150 \mathrm{~g}) \text {. Cook them peeled and diced in } \\
\text { order to eliminate most of the potassium. }\end{array}$} \\
\hline $\begin{array}{l}\text { Unseasoned common bread } \\
\text { Or unsalted crackers } 35 \mathrm{~g} \text {, or } \\
\text { or rice } 50 \mathrm{~g} \text {, or cornmeal mu } \\
\text { (diced and boiled in water). }\end{array}$ & $\begin{array}{l}\text { th no salt } 40 \mathrm{~g} \\
\text { ickbread } 25 \mathrm{~g} \text {, or durum wheat flour pasta } 30 \mathrm{~g} \text {, } \\
75 \mathrm{~g} \text { or (maximum once a week) potatoes } 155 \mathrm{~g}\end{array}$ \\
\hline
\end{tabular}

\begin{tabular}{|c|c|}
\hline \multicolumn{2}{|c|}{ AFTERNOON SNACK } \\
\hline $\begin{array}{l}\text { Type A fruit: } 150 \mathrm{~g} \\
\text { Black cherries, oranges, } \\
\text { strawberries, lemon, quince, } \\
\text { cantaloupe, blueberries, pears, } \\
\text { plums }\end{array}$ & $\begin{array}{l}\text { Or, as an alternative, one of the following: } \\
\text { Type B fruit: } 150 \mathrm{~g} \\
\text { Apricot, pineapple, cherries, } \\
\text { watermelon, kiwi, raspberries, } \\
\text { melon, blackberries, medlars, } \\
\text { peaches, grapefruit } \\
\text { Type C fruit: } 80 \mathrm{~g} \\
\text { Clementines, persimmons, } \\
\text { tangerines, apples, grapes } \\
\text { Type D fruit: } 80 \mathrm{~g} \\
\text { Bananas, figs, mandarins, } \\
\text { pomegranates }\end{array}$ \\
\hline
\end{tabular}

DINNER

\begin{tabular}{|c|c|}
\hline \multicolumn{2}{|r|}{ DINNER } \\
\hline Meat: twice a week & $\begin{array}{l}\text { Choose between: } \\
\text { Type A meat: } 130 \mathrm{~g} \\
\text { Lean lamb, lean baby goat, lean pork, lean } \\
\text { veal, lean beef } \\
\text { Type B meat: } 135 \mathrm{~g} \\
\text { Half-fat lamb, duck, hen, half-fat beef, } \\
\text { chicken (thigh), turkey (thigh), half-fat } \\
\text { veal } \\
\text { Type C meat: } 115 \mathrm{~g} \\
\text { Horse, lean rabbit, pheasant, guinea-fowl, } \\
\text { hare, chicken (breast), quail, turkey } \\
\text { (breast) }\end{array}$ \\
\hline Seafood: twice a week & $\begin{array}{l}\text { Type A fish: } 175 \mathrm{~g} \\
\text { Calamari, mussel, shrimp, prawn, oyster, } \\
\text { octopus, monkfish, ray fish, cuttlefish, } \\
\text { clam } \\
\text { Type B fish: } 130 \mathrm{~g} \\
\text { Anchovy, lobster, crayfish, grouper, } \\
\text { snapper, crab, pike, melù, cod, smooth- } \\
\text { hound, perch, swordfish, rombo, sarago, } \\
\text { sole, bass, tench, trout } \\
\text { Type C fish: } 130 \mathrm{~g} \\
\text { Carp, mullet, surmullet } \\
\text { Type D fish: } 105 \mathrm{~g} \\
\text { Codfish, halibut, gilthead bream, sardine, } \\
\text { stockfish } \\
\text { Type E fish: } 95 \mathrm{~g} \\
\text { Drained tinned tuna in oil, drained tinned } \\
\text { tuna in brine }\end{array}$ \\
\hline $\begin{array}{l}\mathrm{Cl} \\
- \\
- \\
- \\
- \\
-\end{array}$ & $\begin{array}{l}\text { Choose between } \\
\text { Type A cheese: } 100 \mathrm{~g} \\
\text { Sheep ricotta } \\
\text { Type B cheese: } 70 \mathrm{~g} \\
\text { Light cottage cheese, cow ricotta } \\
\text { Type C cheese: } 50 \mathrm{~g} \\
\text { Fresh caciotta, certosino cheese, feta, } \\
\text { buffalo milk mozzarella, stracchino } \\
\text { Type D cheese: } 35 \mathrm{~g} \\
\text { Scamorza } \\
\text { Type E cheese: } 40 \mathrm{~g} \\
\text { Camembert, fior di latte mozzarella, cow } \\
\text { mozzarella, smoked provola, taleggio } \\
\text { cheese }\end{array}$ \\
\hline \multicolumn{2}{|c|}{$\begin{array}{l}\text { Eggs: } 1(60-65 \mathrm{~g}) \text { once every two weeks } \\
\text { Hen egg }\end{array}$} \\
\hline \multicolumn{2}{|c|}{ Once every 15 days the dinner can be replaced with a Margherita pizza. } \\
\hline Cured meats: once a week & $\begin{array}{l}\text { Choose between } \\
\text { Type A cured meat: } 70 \mathrm{~g} \text {. Choose } \\
\text { polyphosphate-free products } \\
\text { Chicken wurstel, turkey wurstel } \\
\text { Type B cured meat: } 45 \mathrm{~g} \\
\text { Lean ham } \\
\text { Type C cured meat: } 35 \mathrm{~g} \text { (bresaola } \\
\text { can replace Parma ham in the same } \\
\text { quantities) } \\
\text { Lean Parma ham }\end{array}$ \\
\hline $\begin{array}{l}\text { Type } \mathbf{A} \text { Vegetable: } 150 \mathrm{~g} \\
\text { Cucumber, onions, aubergines } \\
\text { yellow pepper, red radicchio. }\end{array}$ & $\begin{array}{l}\text { Or, as an alternative, one of the following: } \\
\text { Type B vegetable: } 130 \mathrm{~g} \\
\text { Red beetroot, chard, cardoon, } \\
\text { carrot, chicory, baby onion, fennel, } \\
\text { endive, sweet peppers, salad } \\
\text { tomatoes, ripe tomatoes, peeled } \\
\text { tomatoes, turnip, radish, yellow } \\
\text { pumpkin, courgette } \\
\text { Type C vegetable: } 80 \mathrm{~g} \\
\text { Asparagus, broccoli, artichoke, } \\
\text { cauliflower, Brussels sprouts, red } \\
\text { or green cabbage, catalogna, } \\
\text { sauerkraut, watercress, green } \\
\text { beans, courgette flower, gallinacci } \\
\text { mushrooms, ovuli mushrooms, } \\
\text { porcini mushrooms, field } \\
\text { mushrooms, lettuce, leek, green } \\
\text { radicchio, rocket, endive, celery } \\
\text { Type D vegetable: } 60 \mathrm{~g} \\
\text { chiodini mushrooms, spinach }\end{array}$ \\
\hline \multicolumn{2}{|c|}{$\begin{array}{l}\text { Unseasoned common bread with no salt } 40 \mathrm{~g} \\
\text { Or unsalted crackers } 35 \mathrm{~g} \text {, or stickbread } 25 \mathrm{~g} \text {, or durum wheat flour pasta } 30 \\
\mathrm{~g} \text {, or rice } 50 \mathrm{~g} \text {, or cornmeal mush } 75 \mathrm{~g} \text { or (maximum once a week) potatoes } \\
155 \mathrm{~g} \text { (diced and boiled in water). }\end{array}$} \\
\hline
\end{tabular}

\begin{tabular}{|ll|}
\hline \multicolumn{2}{|c|}{ EVENING SNACK } \\
\hline $\begin{array}{l}\text { Once a week a fruity ice-cream is } \\
\text { allowed } 100 \mathrm{~g} \text { (2 or 3 scoops) }\end{array}$ & Alternatively : \\
& A slice of homemade cake such as \\
& jam tart or apple pie or ring-shaped \\
& cake or madeira cake $80 \mathrm{~g}$, or a slice \\
& of tiramisu or soft dessert $80 \mathrm{~g}$, or a \\
& glass of sugar-free fruit juice 200 ml, \\
& or a piece of dark or milk chocolate \\
& $20 \mathrm{~g}$ \\
\hline & \\
\hline A glass of sugar-free orange juice is allowed every day $(200 \mathrm{ml})$ \\
\hline
\end{tabular}

Fig. 1 Written diet 


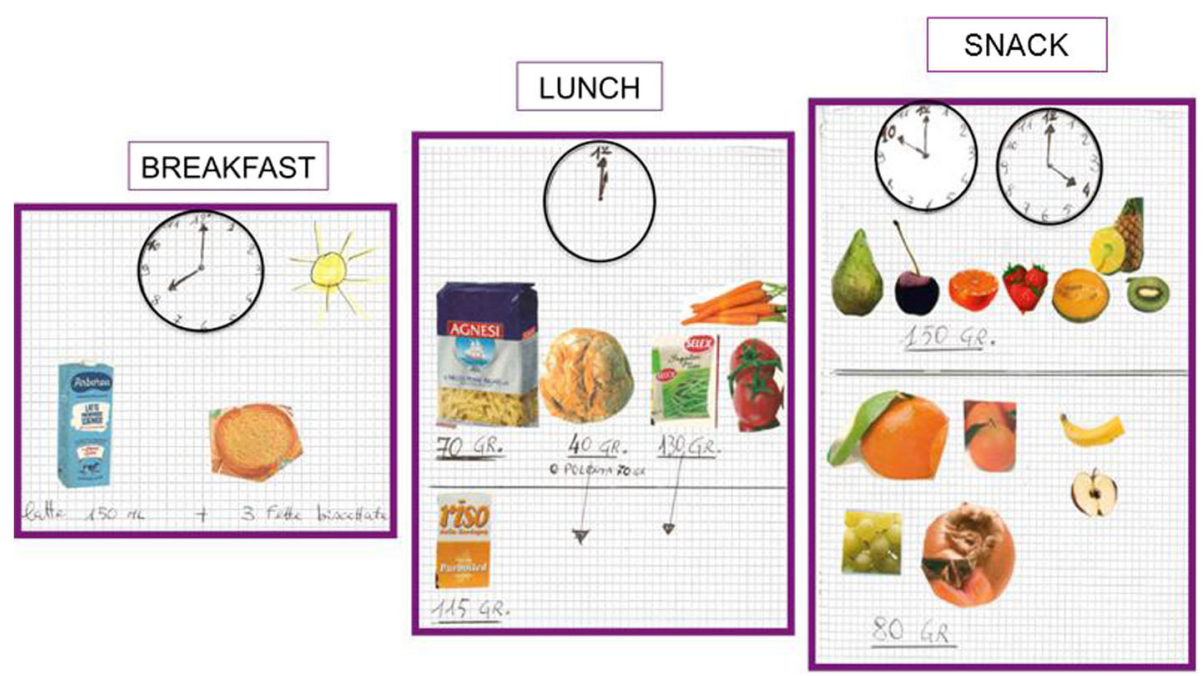

Fig. 2 Visual aid system-diet [1]

program [20]. Khan investigated the main factors of noncompliance in a population of diabetic patients and identified illiteracy as one of the most relevant negative prognostic factors [21]. Ferranti studied pregnant women with a history of gestational diabetes and underlined how patients with a higher education level and self-efficacy were those who followed a mostly adequate diet [22]. The educational level of the family is also important: several studies report an association between high educational level of the parents and quality of their children's diet, both in early age and during adolescence [23].

The literature also shows suggests that, beyond education, the socio-economic level is related to the choice of "good quality" food [24]. Recently, Van Lenthe indicated
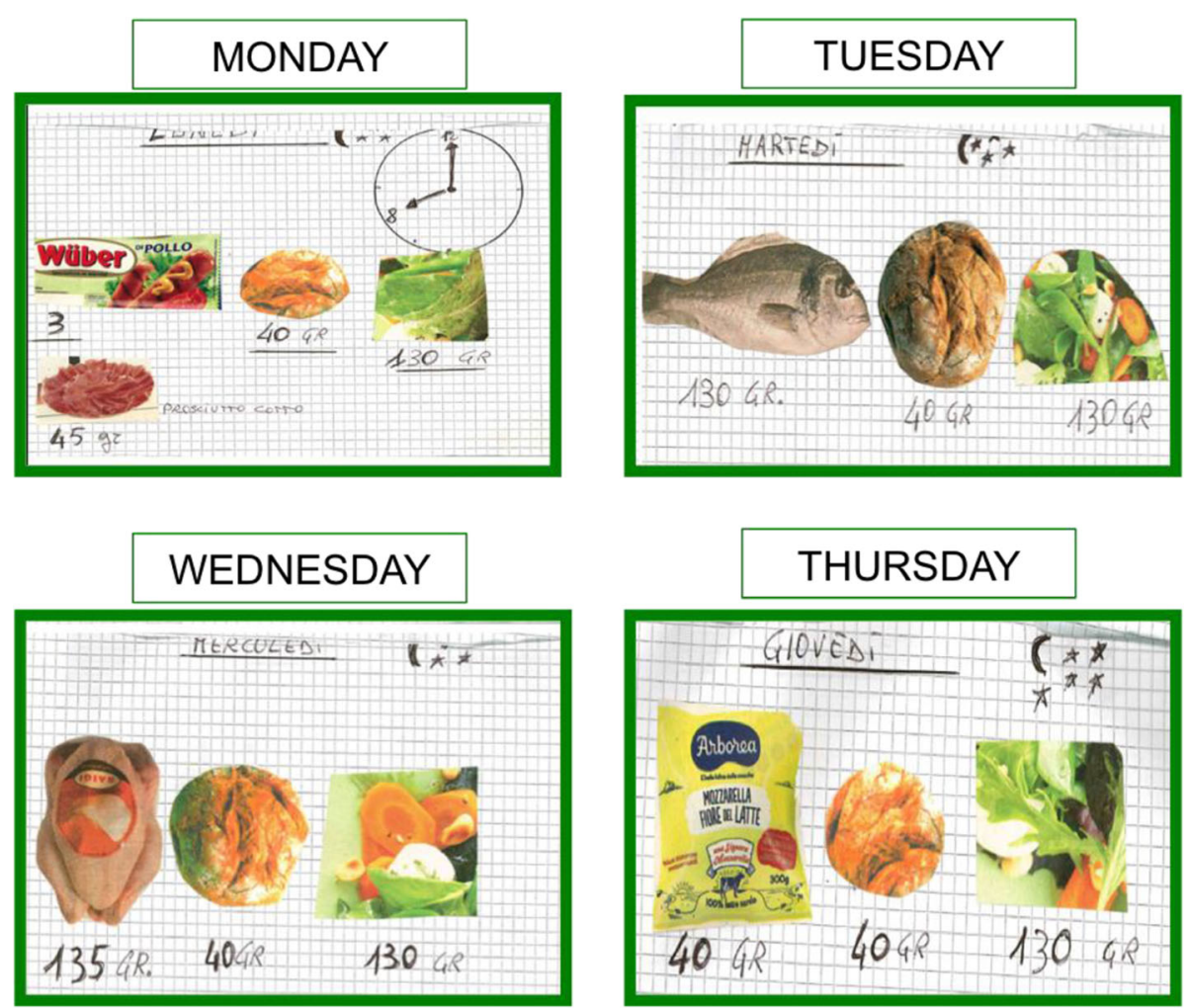

Fig. 3 Visual aid system-diet [2] 


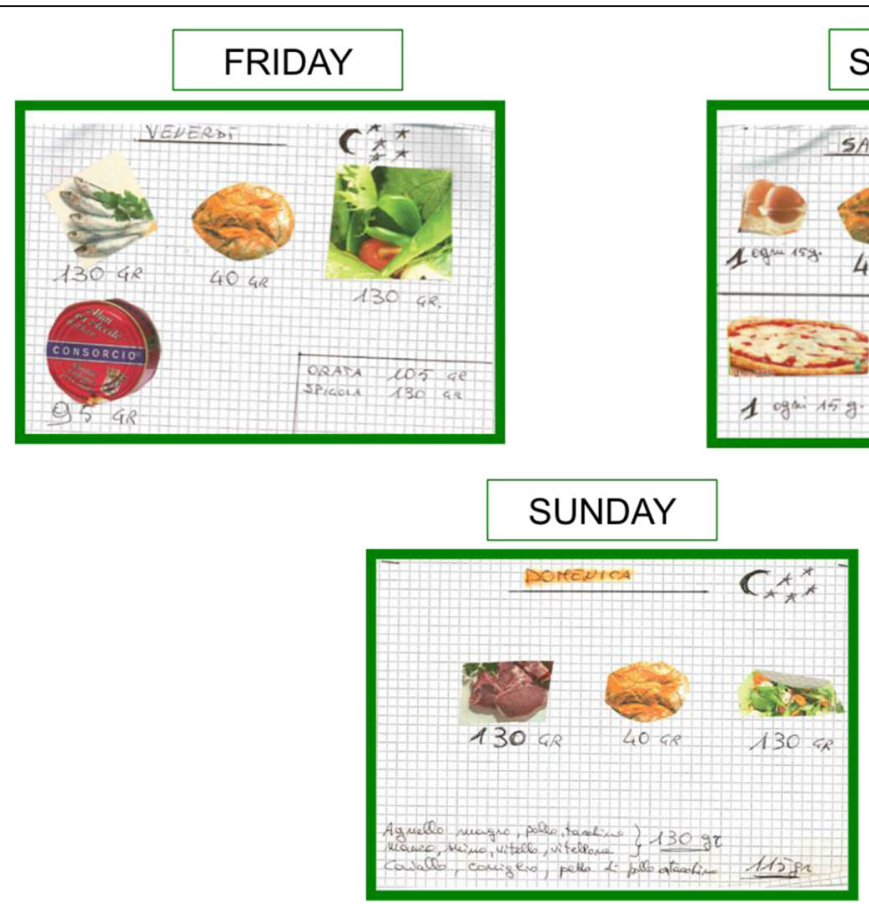

Fig. 4 Visual aid system-diet [3]

that socio-economic inequalities in the choice of healthy food could be explained by differences in the levels of need fulfilment. By dividing people's needs into five categories, according to the Maslow pyramid, the author showed an association between healthy food consumption and self-fulfilment, a category that encompassed the people with a higher educational level [25].

Several diseases are influenced by the socio-economic status: this is the also case of type 2 diabetes, which shares some features with chronic kidney disease, accounting for diet and need for self-management. Walker has recently analysed the association between socio-economic factors, psychological status and disease, highlighting a significant correlation between glycated haemoglobin, education, income, and self-efficacy [26].

Shah compared the treatment burden in celiac patients and in other chronic diseases, including CKD on dialysis. Celiac disease shares with CKD the importance of dietary compliance, which is made more complicated by the need to pay attention to gluten contamination; an issue not shared by CKD patients, who may, on the contrary, profit of occasional unrestricted meals. Also, poor diet compliance in patients with celiac disease has been associated with income (cost of food), lifestyle, educational level and time available to prepare meals [27].

Illiteracy and low socio-economic background have many further correlates, including poor oral status; indeed, our patient presented with chewing difficulties, a significant issue as for malnutrition, especially in the elderly, that should also be taken into account when prescribing a diet [28, 29].

Despite the initial difficulties, the daughter's idea to convert the dietary advice into visual form allowed the patient to follow the diet in an optimal way. This also helped to avoid the risk of undernutrition, or of an unbalanced and over restricted protein intake, which could potentially be more deleterious than a high protein intake, both with respect to general health and to residual kidney function (Table 1).

As shown in the figures, using the symbols of a clock, the sun and the moon with the stars, the woman could understand what meal the pictures referred to. The patient knew that pasta, rice and bread had to be replaced by protein-free food in order to reduce total protein intake and to reach the target, calculated by her residual kidney function.

This self-made method achieved the goal of adequate compliance, reducing the patient's "performance stress" and allowing her to follow the diet without depending on her family, who, due to work commitments and personal needs could not provide continuous assistance. In this process, we believe that the use of visual aids also played a fundamental role in reassuring the patient, who was scared with the prospect of starting dialysis primarily because of her family loss. We assume this psychological aspect was important since the patient continued to rely on her support, having learned how to follow her diet correctly. 
This strategy permitted the stabilization of the residual kidney function, thereby fulfilling the patient's wish to delay dialysis as much as possible.

\section{Conclusions}

Our report warns against the discrimination of patients who are illiterate with regard to the prescription of low protein diets and the belief that they have limited understanding and poor compliance. The case described here may highlight how breaking cultural barriers can be empowering and enhance compliance and motivation, which may conversely be strengthened by the clinical success obtained. It also suggests the importance of the family support unit and underlines how CKD involves the whole family, and how family involvement may also be a resource for attaining compliance.

\section{Abbreviations}

ACEi: Angiotensin converting enzyme inhibitors; ARBs: Angiotensin receptor blockers; CKD: Chronic kidney disease; CKD-EPI: Chronic Kidney Disease Epidemiology Collaboration; eGFR: estimated glomerular filtration rate

\section{Acknowledgements}

None.

Availability of data and materials

Not applicable.

\section{Authors' contributions}

SM, VL, GBP and GC conceived and wrote the manuscript. GBP and GC revised the manuscript critically for important intellectual content. All authors read and approved the final manuscript.

\section{Competing interests}

The authors declare that they have no competing interests.

\section{Consent for publication}

The patient provided full informed consent for gathering the data and publishing the case.

\section{Ethics approval and consent to participate}

Not applicable.

\section{Author details}

${ }^{1}$ SC Nephrology and Dialysis, Brotzu Hospital, Piazzale Alessandro Ricchi 1, 09134 Cagliari, Italy. ${ }^{2}$ SS Nephrology, SCDU Urologia, Department of Clinical and Biological Sciences, University of Torino, San Luigi Gonzaga Hospital, Regione Gonzole 10, 10043 Orbassano, Italy. ${ }^{3}$ Nephrologie, Centre Hospitalier Le Mans, 194 av. Rubillard, 72037 Le Mans, France.

Received: 8 April 2016 Accepted: 22 September 2016 Published online: 29 September 2016

\section{References}

1. Mitch WE, Remuzzi G. Diets for patients with chronic kidney disease, still worth prescribing. J Am Soc Nephrol. 2004;15(1):234-7.

2. Franch HA, Mitch WE. Navigating between the Scylla and Charybdis of prescribing dietary protein for chronic kidney diseases. Annu Rev Nutr. 2009;29:341-64

3. Fouque $D$, Aparicio M. Eleven reasons to control the protein intake of patients with chronic kidney disease. Nat Clin Pract Nephrol. 2007;3(7):383-92.

4. Graves JW. The two best reasons NOT to focus on protein restriction in chronic kidney disease. Nat Clin Pract Nephrol. 2007;3(10):E1. author reply E2.

5. Johnson DW. Dietary protein restriction as a treatment for slowing chronic kidney disease progression: the case against. Nephrology (Carlton). 2006;11(1):58-62.
6. Milas NC, Nowalk MP, Akpele L, et al. Factors associated with adherence to the dietary protein intervention in the Modification of Diet in Renal Disease Study. J Am Diet Assoc. 1995;95(11):1295-300.

7. Piccoli GB, Ferraresi M, Deagostini MC, et al. Vegetarian low-protein diets supplemented with keto analogues: a niche for the few or an option for many? Nephrol Dial Transplant. 2013;28(9):2295-305.

8. Paes-Barreto JG, Silva MI, Qureshi AR, et al. Can renal nutrition education improve adherence to a low-protein diet in patients with stages 3 to 5 chronic kidney disease? J Ren Nutr. 2013;23(3):164-71.

9. Morony S, Flynn M, McCaffery KJ, et al. Readability of Written Materials for CKD Patients: A Systematic Review. Am J Kidney Dis. 2015;65(6):842-50.

10. Tuot DS, Cavanaugh KL. Evaluating the Merits of CKD Patient Educational Materials: Readability Is Necessary But Not Sufficient. Am J Kidney Dis. 2015;65(6):814-6.

11. Davis TC, Crouch MA, Wills G, et al. The gap between patient reading comprehension and the readability of patient education materials. J Fam Pract. 1990;31(5):533-8.

12. Marcus EN. The silent epidemic-the health effects of illiteracy. N Engl J Med. 2006;355(4):339-41.

13. Sani R, Tedde A. Maestri e istruzione popolare in Italia tra Otto e Novecento. Interpretazioni, prospettive di ricerca, esperienze in Sardegna. Milano: Vita e Pensiero; 2003.

14. Fan J, Yan P, Wang Y, et al. Prevalence and Clinical Significance of Low T3 Syndrome in Non-Dialysis Patients with Chronic Kidney Disease. Med Sci Monit. 2016;22:1171-9.

15. Carrero JJ, Cozzolino M. Nutritional therapy, phosphate control and renal protection. Nephron Clin Pract. 2014;126(1):1-7.

16. Wu HL, Sung JM, Kao MD, et al. Nonprotein calorie supplement improves adherence to low-protein diet and exerts beneficial responses on renal function in chronic kidney disease. J Ren Nutr. 2013;23(4):271-6.

17. Munson L. Strategies for setting medical nutrition therapy priorities for patients with stage 3 and 4 chronic kidney disease. J Ren Nutr. 2013;23(2):e43-6.

18. Luis $D$, Huang $X$, Sjögren $P$, et al. Renal function associates with energy intake in elderly community-dwelling men. Br J Nutr. 2014;111(12):2184-9.

19. Piccoli GB, Vigotti FN, Leone F, et al. Low-protein diets in CKD: how can we achieve them? A narrative, pragmatic review. Clin Kidney J. 2015;8(1):61-70.

20. Hadžiabdić MO, Mucalo I, Hrabač $\mathrm{P}$, et al. Factors predictive of drop-out and weight loss success in weight management of obese patients. J Hum Nutr Diet. 2015;28 Suppl 2:24-32.

21. Khan AR, Al-Abdul Lateef ZN, Al Aithan MA, et al. Factors contributing to non-compliance among diabetics attending primary health centers in the Al Hasa district of Saudi Arabia. J Family Community Med. 2012;19(1):26-32.

22. Ferranti EP, Narayan KM, Reilly CM, et al. Dietary self-efficacy predicts AHEI diet quality in women with previous gestational diabetes. Diabetes Educ. 2014;40(5):688-99.

23. Jensen BW, von Kappelgaard LM, Nielsen BM, et al. Intervention effects on dietary intake among children by maternal education level: results of the Copenhagen School Child Intervention Study (CoSCIS). Br J Nutr. 2015;113(6):963-74.

24. Béghin $L$, Dauchet $L$, De Vriendt T, et al. Influence of parental socioeconomic status on diet quality of European adolescents: results from the HELENA study. Br I Nutr. 2014;111(7):1303-12.

25. van Lenthe FJ, Jansen T, Kamphuis CB. Understanding socio-economic inequalities in food choice behaviour: can Maslow's pyramid help? Br J Nutr. 2015;113(7):1139-47.

26. Walker RJ, Gebregziabher M, Martin-Harris B, et al. Independent effects of socioeconomic and psychological social determinants of health on self-care and outcomes in Type 2 diabetes. Gen Hosp Psychiatry. 2014;36(6):662-8.

27. Shah S, Akbari M, Vanga R, et al. Patient perception of treatment burden is high in celiac disease compared with other common conditions. Am J Gastroenterol. 2014;109(9):1304-11.

28. Ioannidou E, Swede H, Fares $G$, et al. Tooth loss strongly associates with malnutrition in chronic kidney disease. J Periodontol. 2014;85(7):899-907.

29. Nowjack-Raymer RE, Sheiham A. Numbers of natural teeth, diet, and nutritional status in US adults. J Dent Res. 2007:86:1171-5.

30. Maroni BJ, Steinman TI, Mitch WE. A method for estimating nitrogen intake of patients with chronic renal failure. Kidney Int. 1985;27(1):58-65. 